\title{
PRODUCTION OF CGTASE BY A BACILLUS ALKALOPHILIC CGII STRAIN ISOLATED FROM WASTEWATER OF A MANIOC FLOUR INDUSTRY
}

\author{
Telma Luisa de Freitas ${ }^{1}$; Rubens Monti² ${ }^{2}$ Jonas Contiero ${ }^{3 *}$ \\ ${ }^{1}$ Departamento de Bioquímica e Tecnologia, Universidade Estadual Paulista Júlio Mesquita Filho, Araraquara, SP, Brasil; \\ ${ }^{2}$ Departamento de Alimentos e Nutrição, Faculdade de/ FCF/ Universidade Estadual Paulista Júlio Mesquita Filho, \\ Araraquara, SP, Brasil; ${ }^{3 *}$ Departamento de Bioquímica e Microbiologia, Instituto de Biociências, Universidade \\ Estadual Paulista Júlio Mesquita Filho, Rio Claro, SP, Brasil.
}

Submitted: September 19, 2003; Returned to authors for corrections: April 28, 2004; Approved: July 27, 2004

\begin{abstract}
GCTase production by a new strain of Bacillus alkalophilic CGII isolated from Brazilian wastewater of manioc flour industry was examined. The growth medium used was composed by $1.5 \%$ starch, $1.5 \%$ nitrogen and $1 \% \mathrm{Na}_{2} \mathrm{CO}_{3}$. Higher activity was obtained with starch, maltodextrin and galactose. When glucose was added to the medium, no enzyme production was observed. High enzyme activity and growth were reached when aeration was increased $(88.6 \mathrm{U} / \mathrm{mL})$. The enzyme characterization showed an optimum $\mathrm{pH}$ and temperature 8.0 and $55^{\circ} \mathrm{C}$ for starch hydrolyses, respectively. $\mathrm{Mg}^{+}$and $\mathrm{Ca}^{++}$showed small activation; however, $\mathrm{Hg}^{+}$and $\mathrm{Cu}^{+}$showed a strong enzyme inhibition.
\end{abstract}

Key words: Bacillus alkalophilic CGII; CGTase; $\beta$-cyclodextrin; starch hydrolysis; enzyme activity

\section{INTRODUCTION}

The enzyme CGTase (cyclodextrin glycosyltransferase) converts starch into cyclic maltooligosaccharide known as cyclodextrin $(1,20,21,27)$. Cyclodextrin $(C D)$ may contain six $\left(\alpha-\mathrm{CD}\right.$, cyclohexamilose $\left.\mathrm{cG}_{6}\right)$, seven $(\beta-\mathrm{CD}$ cycloheptamilose $\left.\mathrm{cG}_{7}\right)$, or eight $\left(\gamma-\mathrm{CD}\right.$, cyclooctamilose $\left.\mathrm{cG}_{8}\right)$ units linked by $\alpha$ 1,4 glycosidic bonds $(3,31)$. The main difference among them is the apolar cavity size and solubility in water (2). The CDs have the capability to form inclusion complexes with a variety of molecules, modifying their physical chemical properties. In general, this is the reason why CDs are being widely used in food, pharmacy and cosmetics industries $(2,23,26,27)$. Several microorganisms are CGTase producers, but the genus Bacillus is the most frequently cited in the literature $(1,3,5,9,11,12,13,14,15,17,18,19,20,21,24,25,30)$. In this work an alkalophilic CGTase producer microorganism, characterized as Bacillus alkalophilic CGII was isolated from wastewater of manioc flour industry. The main objective of the work was to improve the production of CGTase and to characterize the enzyme partially.

\section{MATERIALS AND METHODS}

\section{Isolation of the CGTase producer microorganism}

To isolate the CGTase producer microorganism, the method described by Park et al. (22) was used. Soil samples of $1 \mathrm{~g}$ were suspended in $50 \mathrm{~mL}$ of sterilized water and $0.1 \mathrm{~mL}$ of the suspensions was inoculated in plates containing culture medium prepared with $2.0 \%$ soluble starch (Ecibra); $0.5 \%$ polypeptone (Oxoid); $0.5 \%$ yeast extract (Oxoid); $0.1 \% \mathrm{~K}_{2} \mathrm{HPO}_{4}$ (Synth); $0.02 \% \mathrm{MgSO}_{4} \times 7 \mathrm{H}_{2} \mathrm{O}$ (Synth) $1.0 \% \mathrm{Na}_{2} \mathrm{CO}_{3}$ (Mallinckrodt); $2.0 \%$ Agar (Difco); $0.03 \%$ phenolphthalein (Synth) and $0.01 \%$ methyl orange (Merck), pH 10.5, and incubated at $37^{\circ} \mathrm{C}$. Light zones were observed around the CGTase producer colonies due to phenolphthalein inclusion in the medium by the cyclodextrin produced. The CGTase producer colonies were transferred into tubes containing the

*Corresponding author: Mailing address. Instituto de Biociências de Rio Claro, UNESP, Caixa Postal 199. 13506-900, Rio Claro, SP, Brasil. Fax: (+5519) 35264176. E-mail: jconti@rc.unesp.br 
same culture medium but without phenolphthalein and methyl orange.

\section{CGTase production}

The selected strain was cultivated in flasks containing 200 $\mathrm{mL}$ of culture medium and incubated at $37^{\circ} \mathrm{C}$ during 18 hours at $200 \mathrm{rpm}$. This culture was used to inoculate $(10 \% \mathrm{~V} / \mathrm{V}) 2 \mathrm{~L}$ of culture medium, in a fermentator ( $5 \mathrm{~L}$ capacity) containing $2 \mathrm{~mL}$ of antifoaming agent. The incubation was done at $37^{\circ} \mathrm{C}, 200 \mathrm{rpm}$ and aeration $1.5 \mathrm{vvm}$. Samples were with drawn periodically to analyze the production of the enzyme, the $\mathrm{pH}$ and the enzymatic activity. To improve the enzyme production, many attempts were made, such as substitution of starch by different carbohydrates, and variation in nitrogen and $\mathrm{Na}_{2} \mathrm{CO}_{3}$ concentration. After enzyme production, the culture was centrifuged, and $3 \%$ of starch was added to the supernatant containing the enzyme for adsorption and desorption in phosphate buffer $10 \mathrm{mM}$ ( $\mathrm{pH} 7.0$ ) containing $\mathrm{NaCl} 2 \mathrm{M}$, acetone $3 \mathrm{~V}$ and ammonium sulphate $70 \%$. The enzyme was dialyzed in distilled water during 12 hours and stored under refrigerated conditions.

\section{Enzymatic activity}

Cell-free enzymatic activity was measured according to Mäkela et al. (16) and Goe and Nene (8). Five mL of the supernatant and $5.0 \mathrm{~mL}$ of a $1 \%$ starch solution [0.1 g of soluble starch; $1.0 \mathrm{~mL}$ $\mathrm{CaCL}_{2}(0.05 \mathrm{M})$ and pure water for a total volume of $\left.10 \mathrm{~mL}\right]$ were mixed in a thermostatic reactor at $50^{\circ} \mathrm{C}$. Samples were taken periodically from the reactors, and inactivated in water at $100^{\circ} \mathrm{C}$ for 5 minutes. The concentration of cyclodextrin was measured by addition of $2.5 \mathrm{~mL}$ of a $3 \mathrm{mM}$ phenolphthalein solution $(5.0 \mathrm{~mL}$ of $0.6 \mathrm{M} \mathrm{Na}_{2} \mathrm{CO}_{3}$ buffer, $\mathrm{pH} 10.5$, and the volume completed with $2.5 \mathrm{~mL}$ of distilled water in a volumetric flask) to $0.5 \mathrm{~mL}$ of the inactivated samples. The absorbance of the final solution was analyzed in spectrophotometer at $550 \mathrm{~nm}$. A unit of the enzymatic activity was defined as the quantity of enzyme that produces 1 $\mu \mathrm{mol}$ of $\beta-\mathrm{CD}$ per minute under standard conditions.

\section{RESULTS AND DISCUSSION}

\section{Isolation of the microorganism}

During the selection of CGTase producer microorganisms, four strains of alkalophilic Bacillus were isolated. The strain that showed highest activity $\beta$-CD production was characterized as Bacillus alkalophilic CGII.

\section{CGTase production}

Table 1 shows the effect of the carbon source on the enzyme synthesis after 48 hours of fermentation. According to the results, the microorganism grew very well in all studied carbon sources, but the growth was slower in mannitol and glucose. Higher specific activities were obtained with starch, maltodextrin and galactose. When glucose was added to the medium, enzyme production was not observed. Fig. 1 shows the effect of starch concentration, showing that the highest activity was reached at $1.5 \%$.

Table 1. Effect of carbohydrate source on the synthesis of CGTase by B. alkalophilic after 48 hour-fermentation.

\begin{tabular}{lrcccc}
\hline $\begin{array}{l}\text { Carbon } \\
\text { Source }\end{array}$ & $\begin{array}{c}\text { Initial } \\
\mathrm{pH}\end{array}$ & $\begin{array}{c}\text { Final } \\
\text { Mass }\end{array}$ & $\begin{array}{c}\text { Dry } \\
(\mathrm{mg} / \mathrm{mL})\end{array}$ & $\begin{array}{c}\text { Activity } \\
\text { Mass } \\
(\mathrm{U} / \mathrm{mL})\end{array}$ & $\begin{array}{c}\text { Specific } \\
\text { Activity } \\
(\mathrm{U} / \mathrm{mg})\end{array}$ \\
\hline Starch & 10.15 & 8.59 & 7.80 & 37.48 & 12.00 \\
Maltodextrin & 10.15 & 9.14 & 5.28 & 15.70 & 7.40 \\
Fructose & 10.00 & 8.74 & 8.36 & 8.90 & 2.66 \\
Lactose & 10.12 & 9.04 & 7.38 & 6.51 & 2.20 \\
Galactose & 10.03 & 9.18 & 4.80 & 6.31 & 3.28 \\
Xylose & 9.95 & 8.77 & 6.30 & 6.20 & 2.46 \\
Wheat bran & 10.02 & 8.99 & $\mathrm{nd}$ & 5.66 & $\mathrm{nd}$ \\
Sucrose & 10.15 & 8.67 & 4.49 & 4.23 & 2.35 \\
Sorbitol & 10.16 & 9.33 & 4.29 & 2.97 & 1.73 \\
Manitol & 10.15 & 8.98 & 3.68 & 2.25 & 1.52 \\
Maltose & 10.08 & 8.64 & 6.80 & 1.54 & 0.57 \\
Glucose & 10.05 & 8.59 & 3.75 & 0.00 & 0.00 \\
\hline
\end{tabular}

nd: not determined.

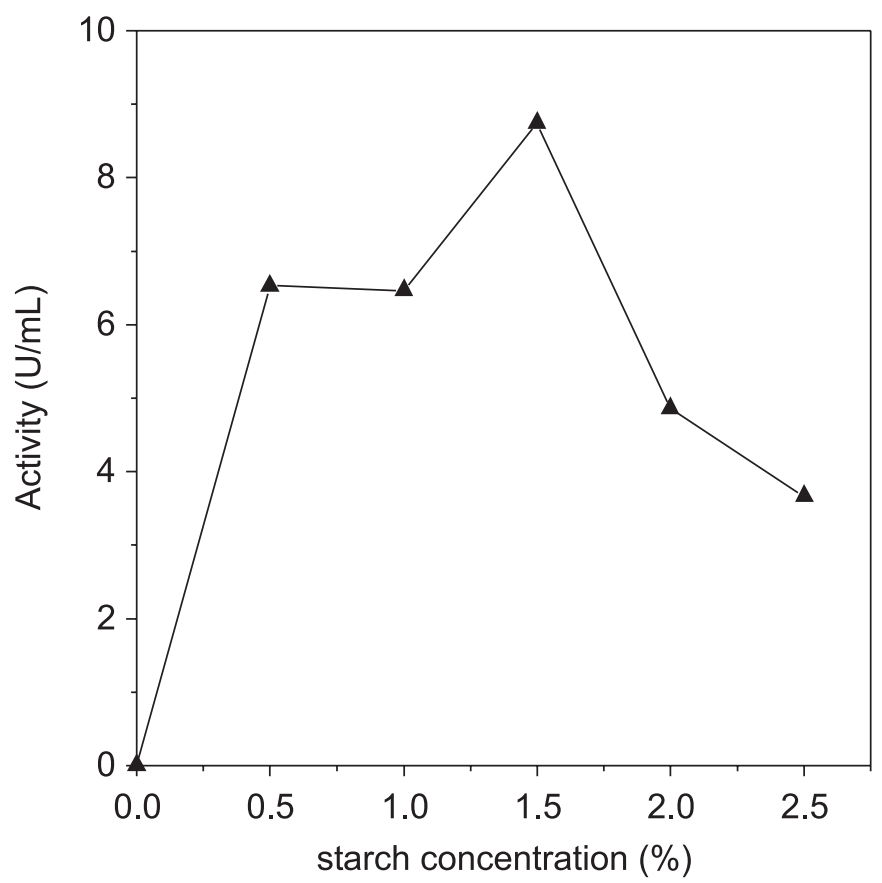

Figure 1. CGTase activity as a function of the starch concentration. 
Fig. 2 shows the effect of nitrogen concentration (yeast extract and peptone) on the cellular growing and enzyme production. It is important to note that the initial $\mathrm{pH}$ is lower for higher nitrogen concentration present in the medium. However; the $\Delta \mathrm{pH}$ was not altered at any concentration. It was verified that, the maximum growth occurred at about 24-30 hours in all concentrations. A diauxie phase was observed at lower concentrations (Fig. 3). At the same time as the nitrogenous concentration increases, the exponential phase becomes longer. The $1.5 \%$ nitrogenous concentration was chosen for the next assays because in this concentration it was possible to achieve a better enzymatic activity in a short period of time, that is, at around 36 hours of fermentation, as shown in Fig. 4.

The effect of $\mathrm{Na}_{2} \mathrm{CO}_{3}$ on cellular growth and enzyme production was studied varying the concentration from $0.25 \%$ to $1.5 \%$. As shown in Fig. 5, the difference between the starting and final $\mathrm{pH}$ in all concentrations tested, did not change, that is, the $\Delta \mathrm{pH}$ was kept almost constant. Regarding to cellular growth, it was observed a larger exponential phase at higher concentrations of $\mathrm{Na}_{2} \mathrm{CO}_{3}$ and an enhanced diauxie at lower concentrations (Fig. 6). At higher concentrations of $\mathrm{Na}_{2} \mathrm{CO}_{3}$ the fermentation time to obtain a good enzymatic activity was the same as for lower concentrations (Fig. 7). Based in this fact, the $1.0 \% \mathrm{Na}_{2} \mathrm{CO}_{3}$ concentration was chosen for the other assays, because the adition to the culture medium is only to increase its $\mathrm{pH}$, and to buffer the medium for the growth of a alkalophilic microorganism.

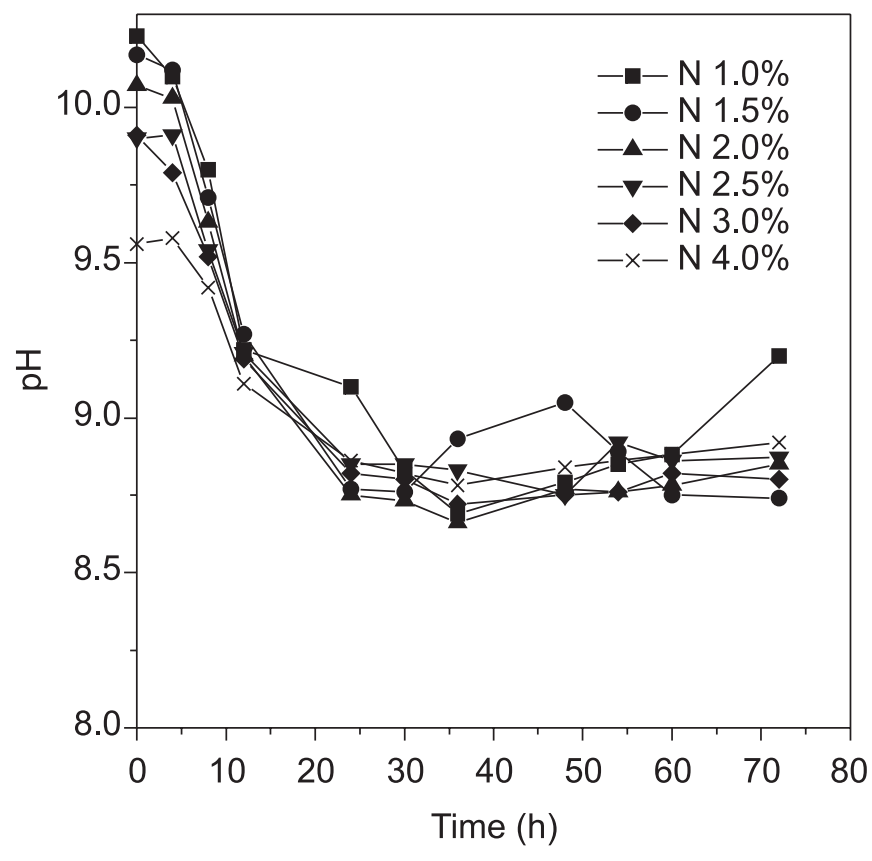

Figure 2. $\mathrm{pH}$ as a function of nitrogen concentration: (ם) $1 \%$; (O) $1.5 \% ;(\Delta) 2.0 \% ;(\nabla) 2.5 \% ;(\diamond) 3.0 \%$; (X) $4.0 \%$.

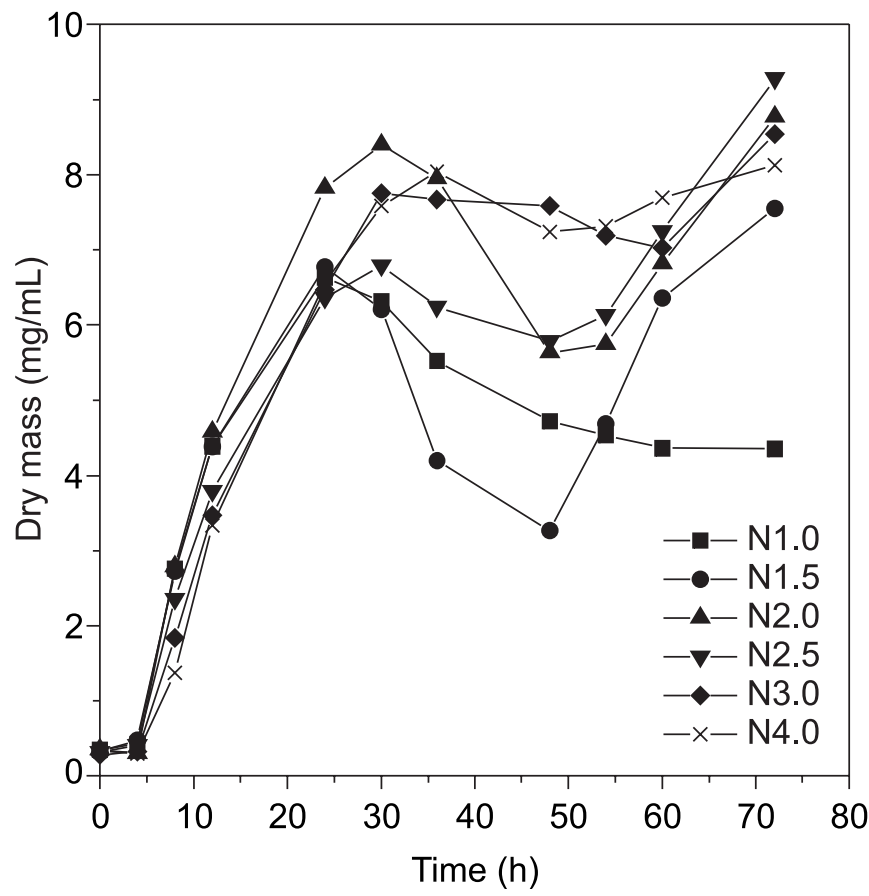

Figure 3. Dry mass as a function of nitrogen concentration: ( $1 \% ;(\mathbf{O}) 1.5 \% ;(\boldsymbol{\Delta}) 2.0 \% ;(\boldsymbol{\nabla}) 2.5 \%$; $(\diamond) 3.0 \%$; (X) $4.0 \%$.

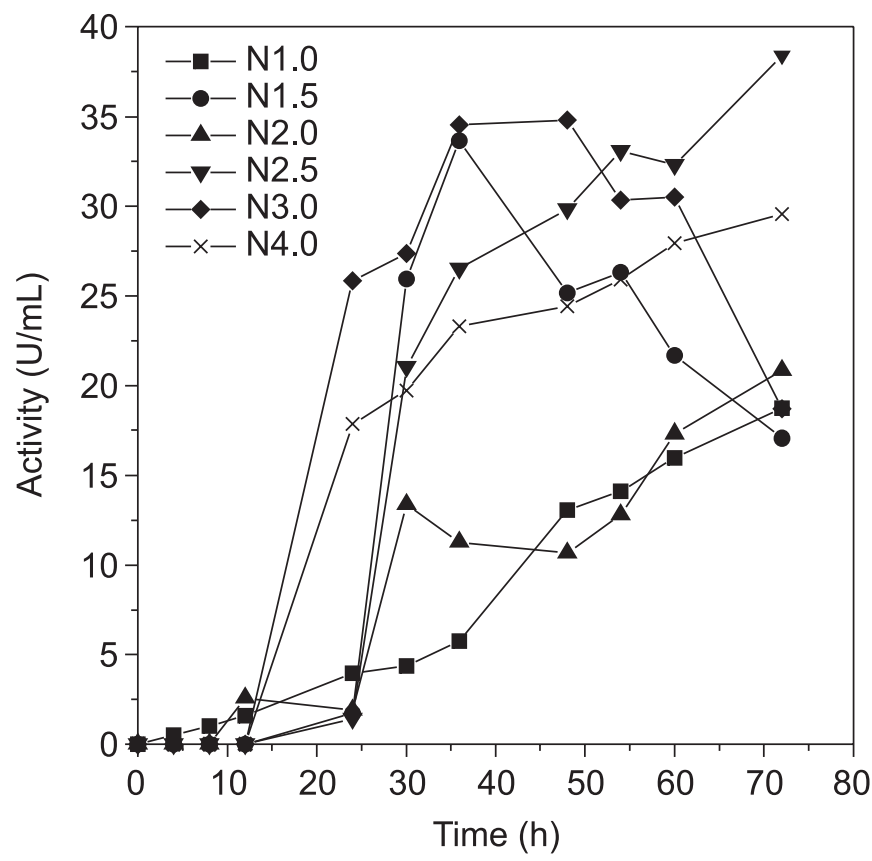

Figure 4. Enzymatic activity as a function of nitrogen

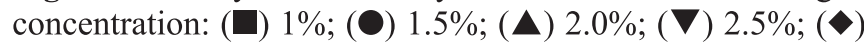
$3.0 \% ;(\mathrm{X}) 4.0 \%$. 


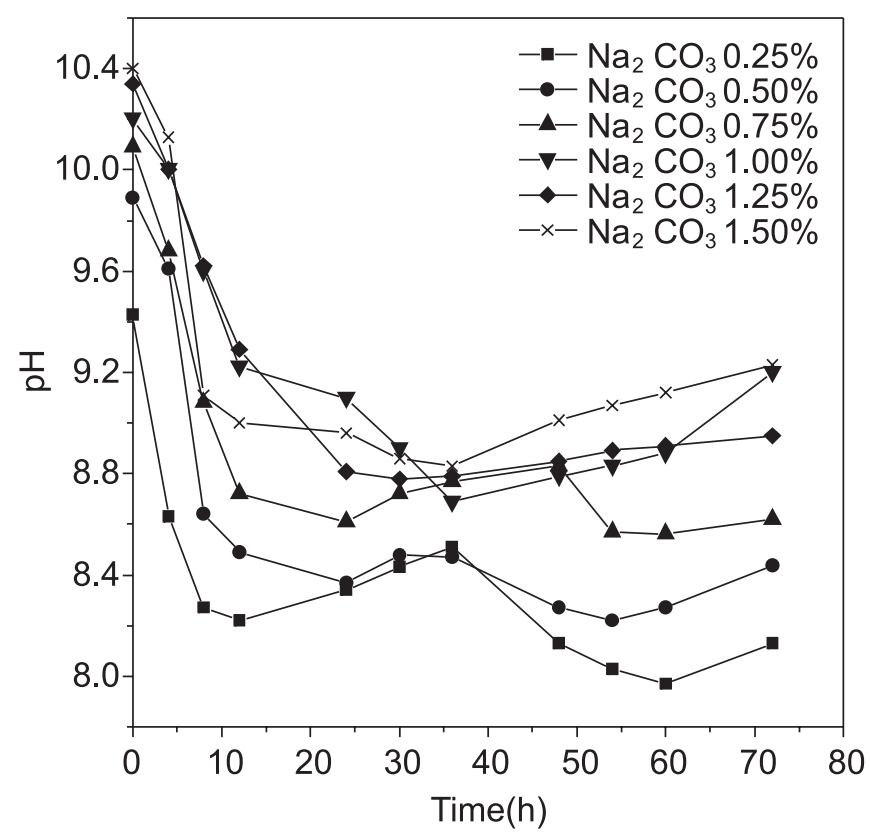

Figure 5. $\mathrm{pH}$ as a function of $\mathrm{Na}_{2} \mathrm{CO}_{3}$ concentration: $0.25 \%$; (○) $0.5 \%$; (A) $0.75 \%$; ( $1.5 \%$.

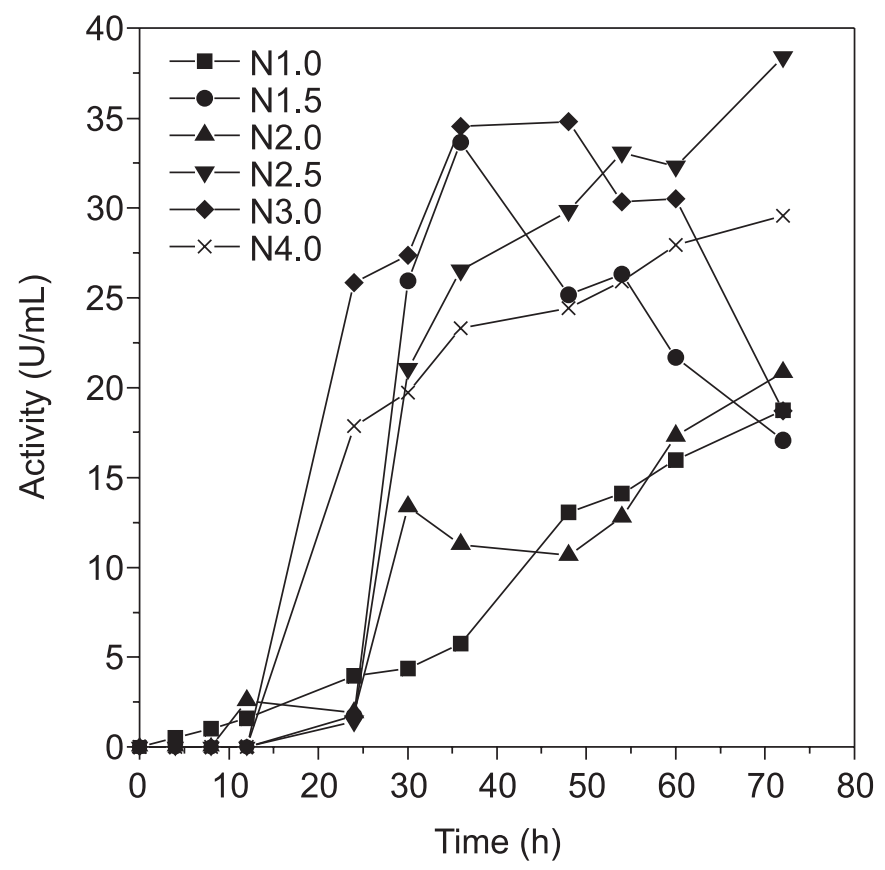

Figure 7. Enzymatic activity as a function of $\mathrm{Na}_{2} \mathrm{CO}_{3}$

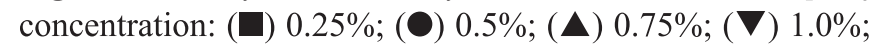
$(\bullet) 1.25 \%$; (X) $1.5 \%$

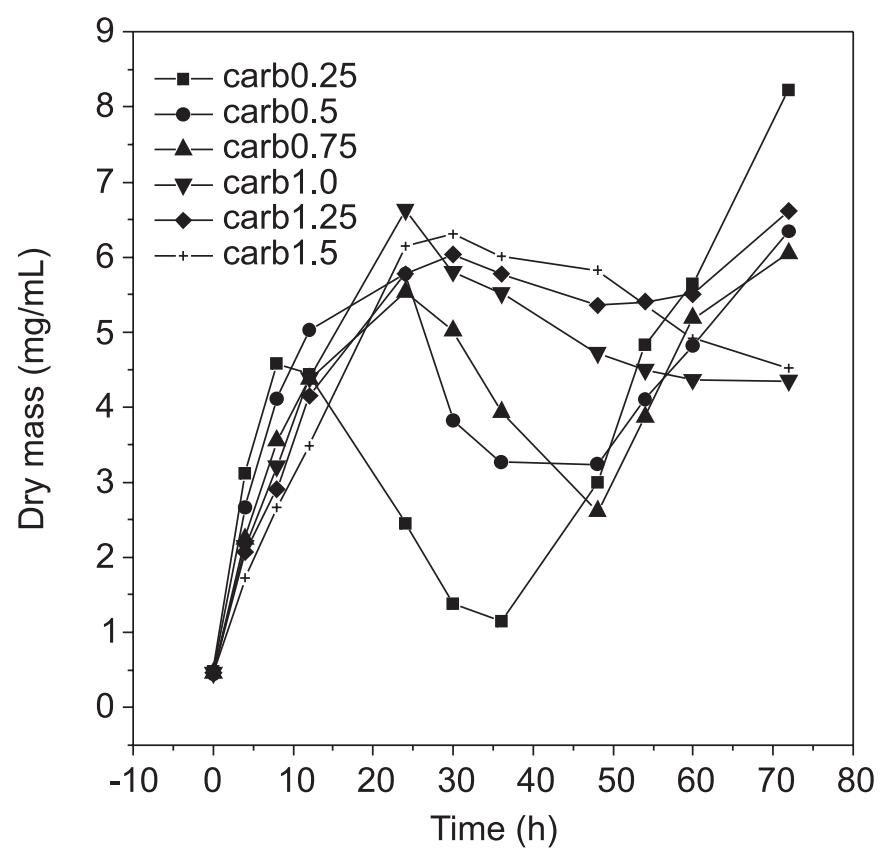

Figure 6. Dry mass as a function of $\mathrm{Na}_{2} \mathrm{CO}_{3}$ concentration: ( $\square$ )

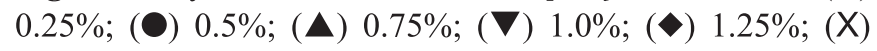
$1.5 \%$.

It was observed that the use of antifoaming at $0.05 \%(\mathrm{v} / \mathrm{v})$ did not influence the enzymatic production, and that the aeration of $1.5 \mathrm{vvm}$ allowed a production of $88.6 \mathrm{U} / \mathrm{mL}$.

\section{Enzyme characterization}

For partial enzyme characterization in the supernatant three concentration methods were used: a) precipitation with ammonium sulphate $(70 \%)$; b) precipitation with $3 \mathrm{~V}$ acetone; c) adsorption with starch and elution with $\mathrm{NaCl} 2 \mathrm{~N}$. The specific activity was determined. Precipitation with ammonium sulphate and acetone showed the best yields. The enzyme obtained by these two methods was submitted to chromatography in DEAETrysacryl, achieving a purification of 11.7 times. SDS-PAGE of the active fraction showed three proteic bands, and one of them was CGTase. Other studies of characterization were made with the partially purified enzyme. Figs. 8 and 9 show the effect of $\mathrm{pH}$ and temperature on the enzymatic activity, respectively. The optima $\mathrm{pH}$ and temperature for starch hydrolysis were 8.0 and $55^{\circ} \mathrm{C}$ respectively. Thatai et al. (29) determined a $\mathrm{pH}$ of 6.6 and temperature of $65^{\circ} \mathrm{C}$ and Gawande et al. (7) found the optimal temperature of $65^{\circ} \mathrm{C}$ for CGTase from Bacillus firmus. Table 2 shows the results obtained with various metallic ions and EDTA. $\mathrm{Mg}^{+}$and $\mathrm{Ca}^{+}$showed little activation. However, $\mathrm{Hg}^{+}$and $\mathrm{Cu}^{+}$ showed a strong inhibition, while the remaining ions showed weak inhibition. These results contrast with the ones obtained by Fujita et al. (6) who verified a strong inhibition for $\mathrm{Zn}^{2+}, \mathrm{Fe}^{2+}$ 


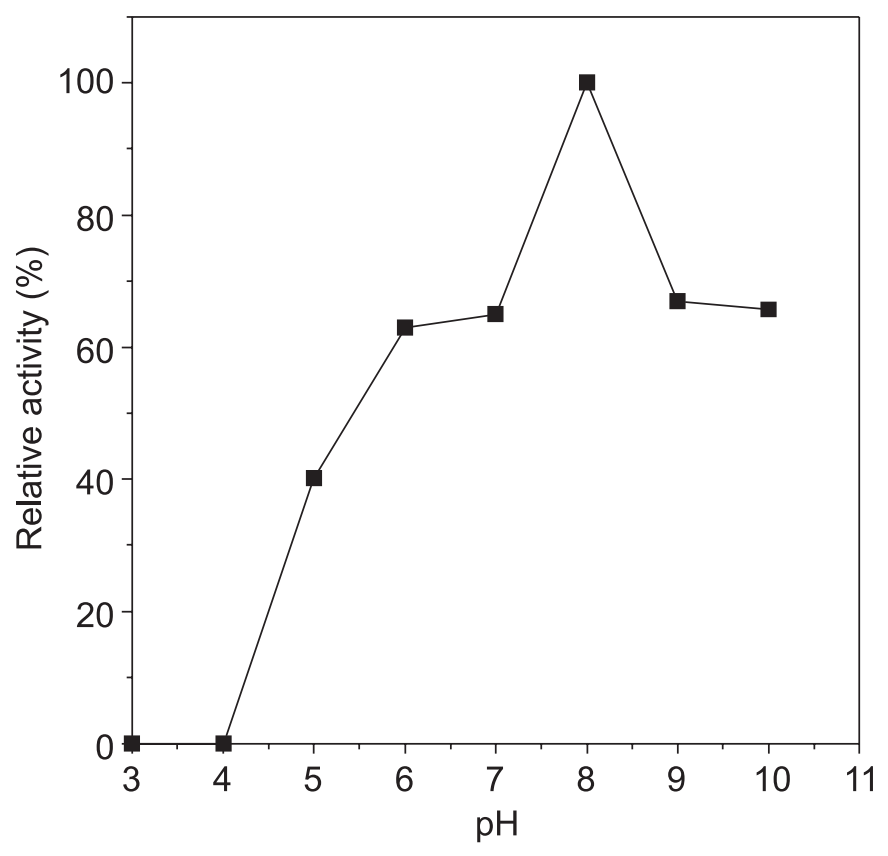

Figure 8. Enzymatic activity as a function of $\mathrm{pH}$, using the following buffers $50 \mathrm{mM}$ citrate-phosphate ( $\mathrm{pH} \mathrm{3.0),} 50 \mathrm{mM}$ sodium acetate ( $\mathrm{pH} 4.0-6.0), 50 \mathrm{mM}$ Tris- $\mathrm{HCl}(\mathrm{pH} 7.0-9.0)$ and $50 \mathrm{mM}$ carbonate/bicarbonate $(\mathrm{pH} \mathrm{10.0)}$.

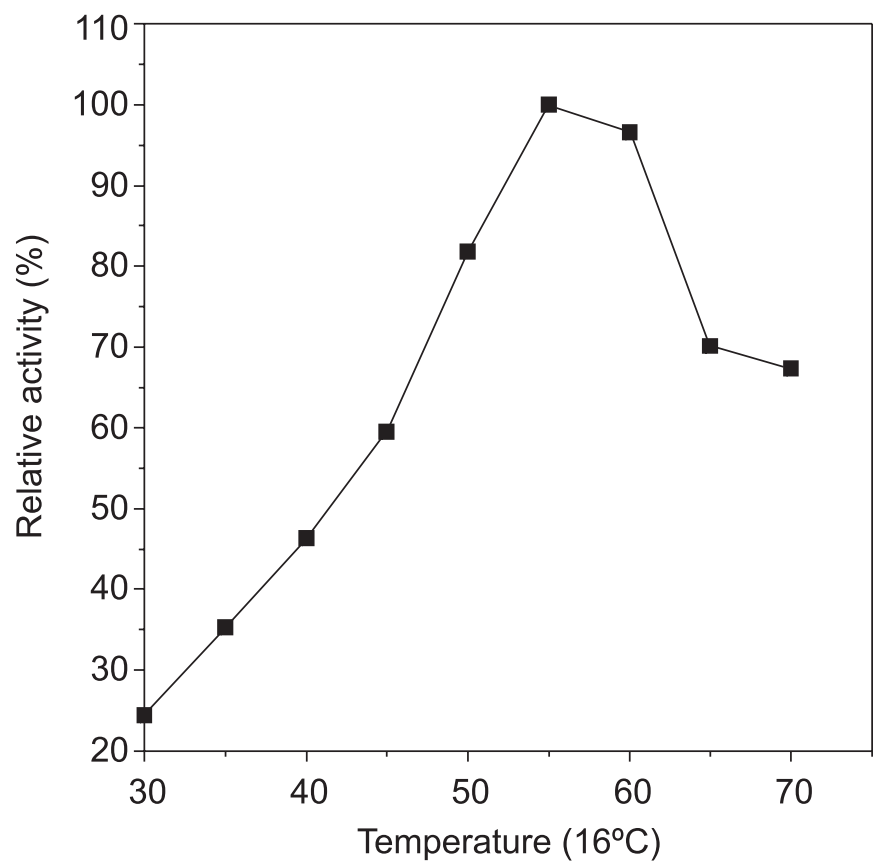

Figure 9. Enzymatic activity as a function of temperature: Conditions: $\mathrm{pH} 8.0 ; 1 \%$ starch solution containing $\mathrm{CaCl}_{2}$ $0.05 \mathrm{M}$.
Table 2. Effect of the ions and EDTA on the enzymatic activity.

\begin{tabular}{cc}
\hline Ions $(5 \mathrm{mM})$ & Relative activity $(\%)$ \\
\hline Control & 100 \\
$\mathrm{Mg}^{2+}$ & 109 \\
$\mathrm{Ca}^{2+}$ & 105 \\
$\mathrm{KCl}$ & 92 \\
$\mathrm{Fe}^{2+}$ & 90 \\
$\mathrm{EDTA}^{2+}$ & 88 \\
$\mathrm{Co}^{2+}$ & 87 \\
$\mathrm{Mn}^{2+}$ & 80 \\
$\mathrm{Zn}^{2+}$ & 61 \\
$\mathrm{Cu}^{2+}$ & 33 \\
$\mathrm{Hg}^{2+}$ & 6 \\
\hline
\end{tabular}

and $\mathrm{Cu}^{2+}$ and a stability in the presence of $\mathrm{Hg}^{2+}$ for the enzyme of Bacillus sp. AL-6.

The results indicate that $B$. alkalophilic CGII is a good CGTase producer when compared to the other microorganisms. Further studies are needed in order to optimize the enzyme production and the quantification of $\beta$-cyclodextrin production by HPLC analysis and to explore the biotechnological potential of this enzyme.

\section{RESUMO}

\section{Produção de CGTase por Bacillus alkalophilic CGII isolado de água residuária de uma fecularia de mandioca}

Estudou-se a produção de CGTase por uma nova cepa de Bacillus alkalophilic CGII, isolada de água residuária de uma fecularia de mandioca, durante cultivo em meio composto de $1,5 \%$ de amido, $1,5 \%$ de fonte de nitrogênio e $1 \% \mathrm{Na}_{2} \mathrm{CO}_{3}$. A atividade enzimática foi alta quando se utilizou amido, maltodextrina e galactose como fontes de carbono. Quando se utilizou glicose no meio de cultivo não se observou produção da enzima. Atividade enzimática alta $(88,6 \mathrm{U} / \mathrm{mL})$ e melhor crescimento foram obtidos quando se aumentou a aeração. A caracterização da enzima mostrou um $\mathrm{pH}$ ótimo de 8,0 e temperatura ótima de $55^{\circ} \mathrm{C}$ sendo que a enzima sofreu uma pequena ativação por $\mathrm{Mg}^{+}$ e $\mathrm{Ca}^{++}$. A enzima foi fortemente inibida por $\mathrm{Hg}^{+} \mathrm{e} \mathrm{Cu}^{+}$.

Palavras-chave: Bacillus alkalophilic CGII, CGTase, $\beta$ ciclodextrina, hidrólise do amido, atividade enzimática

\section{REFERENCES}

1. Abelyan, V.A.; Yamamoto, T.; Afrykyan, E.G. On the mecanism of action of cyclomaltodextrin glucotransferase of alkalophilic, 
termophilic and mesophilic microorganisms. Biochem. 59(8):839844, 1994.

2. Allegre, M.; Deratani, A. Cyclodextrin uses: from concept to industrial reality. Agro-Food Industry Hi-Tech, 1994, p. 9-17.

3. Bender, H. An improve method for the preparation of cyclodextrin octaamylose, using starches and the cyclodextrin glicosyltransferase of Klebsiella pneumoniae M 5 al. Carbohydr. Res.124:225-233, 1986.

4. Bender, H. Production, characterization and application of cyclodextrins. Adv. Biotechnol. Process. 6:37-71,1986.

5. Freitas T L. Produção e caracterização da CGTase produzida por Bacillus sp. Araraquara, 2001, 77 p. (M. Sc. Dissertação, Instituto de Química de Araraquara, Unesp).

6. Fugita, Y; Tsubouchi, H.; Inagi, Y.; Tomita, K.; Ozaki, A.; Nakanishi, K. Purification and properties of Cyclodextrin Glycosiltransferase from Bacillus sp AL-6. J. Ferm. Bioeng. 70(3):150-154,1990.

7. Gawande, B.N.; Goel, A.; Patkar, A.Y.; Nene, S.N. Purification and properties of a novel raw starch degrading cyclodextrin glucanosiltransferase from Bacillus firmus. Appl. Microbiol. Biotechnol. 51:504-509,1999.

8. GoeL, A.; Nene, S.N. Modifications in the phenolphthalein method for spectrophotometric estimation of beta-cyclodextrin. Starch/ Stärke. 47(10):399-400, 1995.

9. HorikoshI, K. Production of alkaline enzymes by alkalophilic microorganisms. Part II. Alkaline amilase produced by Bacillus $\mathrm{N}^{\circ}$. A-40-2. Agr. Biol. Chem. 35(11):1783-1791, 1971.

10. Horikoshi, K. Production and industrial applications of $\beta$ cyclodextrin. Process. Biochem. 14(5):26-30,1979.

11. Jamuna, R.; Saswathi, N.; Sheela, R.; Ramakrishna, S.V. Syntesis of cyclodextrin-Glucosiltransferase by Bacillus cereus for the production of cyclodextrins. Appl. Biochem. Biotechnol. 43:163-176,1993.

12. Kitahata, S.; Tsuyama, N.; Okada, S. Purification and some properties of Cyclodextrin Glycosyltransferase from a strain of Bacillus sp. Agr. Biol. Chem. 38(2):387-393, 1974.

13. Kitahata, S.; Okada, S. Purification and some properties of cyclodextrin glycosyltransferase from Bacillus Stearothermophilus TC-60. J. Jap. Soc. Starch Sci. 29(1):7-12,1982.

14. Kobayashi, S.; Kainuma, K.; SuzukI, S. Purification and some properties of Bacillus macerans cycloamylose (cyclodextrin) glucanotransferase. Carbohydr. Res. 61:229-238, 1977.

15. KometanI, T.; Terada, Y.; Nishimura, T.; Takii, H.; Okada, S. Purification and characterization of cyclodextrin glucanotransferase from an alkalophilic Bacillus species and transglycosylation at alkaline pHs. Biosci. Biotechnol. Biochem. 58(3):517-520, 1994.

16. Mäkelä, M.J.; Korpela, T.; Laakso, S. Colorimetric determination of $\beta$-cyclodextrin: two assay modifications based on molecular complexation of phenolphtalein. J. Biochem. Biophys. Meth. 14: 85-92, 1987.
17. Mäkelä, M.J.; Paavilainen, S.K.; Korpela, T.K. Growth dynamics of cyclomaltodextrin glucanotransferase producing Bacillus circulans var. alkalophilus. Can. J. Microbiol. 36:176-182,1990.

18. Maréchal, L.R.; Rosso, A.M,; Maréchal, M.A.; Krymkiewicz, N.; Ferrarotti, S.A. Some properties of a cyclomaltodextringlucanotransferase from Bacillus circulans DF 9R type. Cell. Mol. Biol. 42(5):659-664, 1996.

19. Matioli, G.; Zanin, G.M,; Guimaraes, M.F.; De Moraes, F.F. Production and purification of CGTase of alkalophylic Bacillus isolated from Brazilian soil. Appl. Biochem. Biotechnol. 70(2):267-275, 1998.

20. Nakamura, N.; Horikoshi, K. Characterization and some cultural conditions of a cyclodextrin-glycosyltransferase-producing alkalophilic Bacillus sp. Agr. Biol. Chem. 40(4):753-757, 1976 .

21. Nakamura, N.; Horikoshi, K. Purification and properties of cyclodextrin glycosyltransferase of alkalophilic Bacillus sp. Agric. Biol. Chem. 40(9):935-941, 1976b.

22. Park, C.S.; Park, K.H.; Kim, S.H. A rapid screening method for alkaline $\beta$-cyclodextrin glucanotransferase using phenolphthaleinmethylorange containing solid medium. Agric. Biol. Chem. 53(4):1167-1169,1989.

23. Pczczola, D.E. Production and potencial food application of cyclodextrins. Food Technol. 42: 96-100,1988.

24. Sabioni, J.G.; Park, Y.K. Production and characterization of cyclodextrin glycosyltransferase from Bacillus lentus. Starch/Stärke. 44(6):225-229, 1992

25. Sin, K.; Nakamura, A.; Masaki, H.; Uozumi, T. Extracellular production of Bacillus ohbensis cyclodextrin glucosiltransferase by Bacillus subtilis. Biosci. Biotechnol. Biochem. 57(2):346-347,1993.

26. Starnes, R.L. Industrial potencial of cyclodextrin glycosyltransferases. Cereal Food World. 35:1094-1099,1990.

27. Szejtli, J. Utilization of cyclodextrins in industrial products and process. J. Mater. Chem. 7(4): 575-587,1997.

28. Terada, Y.; Yanase, M,; Takata, T.; Okada, S. Cyclodextrins are not the major cyclic $\alpha-1,4$-glucans produced by the initial action of cyclodextrin glucanotransferase on amylase. J. Biol. Chem. 272(25):15729-15733,1997.

29. Thatai, A.; Kumari, M.; Mukherjee, K.J. A single step purification process for cyclodextrin glucanosiltransferase from a Bacillus sp. Isolated from soil. Preparative Biochem. Biotechnol. 29(1):3547,1999.

30. Tomita, K.; Kaneda, M.; Kawamura, K.; Nakanishi, K. Purification and properties of a cyclodextrin glucanotransferase from Bacillus autolyticus 1149 and selective formation of $\beta$-cyclodextrin. J. Ferm. Bioeng. 75(2):89-92, 1993.

31. Yim, D.G.; Sato, H.H.; Park, Y.H.; Park, Y.K. Production of cyclodextrin from starch by cyclodextrin glycosyltransferase from Bacillus firmus and characterization of purified enzyme. J. Ind. Microb. Biotechnol. 18:402-405, 1997. 